\title{
Chemical characterization of black poplar (Populus nigra L.) sawdust hemicelluloses esterified with acyl chlorides
}

\author{
Samim Yaşara,* (D), Gürcan Gülera (iD
}

\begin{abstract}
In the present study, hemicelluloses were isolated from black poplar (Populus nigra L.) sawdust, which is generated by the wood industry in large quantities as lignocellulosic waste. The monosaccharide composition of hemicelluloses was determined by gas chromatography. Xylose was the predominant monosaccharide unit, at $81.13 \%$. Isolated hemicelluloses were then esterified with octanoyl, decanoyl, and lauroyl chloride, and the produced derivatives were characterized in terms of percent yield, degree of substitution (DS), solubility, Fourier-transform infrared spectroscopy (FTIR), and thermogravimetric analysis (TGA). Hemicellulose derivatives had DS values ranging from 0.83 to 0.97 , and percent yields ranging from $61.54 \%$ to $62.31 \%$. FTIR analysis confirmed esterification. TGA indicated that the hemicellulose derivatives offered lower thermal stabilities than native hemicelluloses. Solubility analysis indicated that esterification increased the hydrophobic capacity of hemicelluloses. Generally, the hemicellulose derivatives obtained could be used to make biodegradable and environmentally friendly plastics, resins, films, and coatings for industrial utilization.
\end{abstract}

Keywords: Degree of substitution, Esterification, Hemicelluloses, Percent yield, Solubility, Thermal stability

\section{Açil klorürler ile esterlenmiş karakavak (Populus nigra L.) talaşına ait hemiselülozlarm kimyasal karakterizasyonu}

\begin{abstract}
Özet: Bu çalışmada, orman ürünleri endüstrisinde büyük miktarlarda lignoselülozik atık olarak açığa çıkan karakavak (Populus nigra L.) talaşından hemiselülozlar izole edilmiştir. Hemiselülozların monosakkarit bileşimi gaz kromatografisi ile belirlenmiştir. Ksiloz, \%81.13 ile baskın monosakkarit birimi olarak tespit edilmiştir. İzole edilmiş hemiselülozlar daha sonra oktanoil, dekanoil ve lauroil klorür ile esterlenmiş ve elde edilen türevler yüzde verim, sübstitüsyon derecesi (DS), çözünürlük, Fourier dönüşümlü kızı̈ötesi spektroskopisi (FTIR) ve termogravimetrik analiz (TGA) ile karakterize edilmiştir. Hemiselüloz türevlerinin DS değerleri 0.83 ile 0.97 arasında değişirken, yüzde verimleri \%61.54 ile \%62.31 arasında yer almıştır. FTIR analizi esterlenmeyi destekleyen sonuçlar sunmuştur. TGA, hemiselüloz türevlerinin, doğal hemiselülozlardan daha düşük termal stabiliteye sahip olduklarını göstermiştir. Çözünürlük analizi, esterlenmenin hemiselülozların hidrofobik kapasitesini geliştirdiğini ortaya koymuştur. Genel olarak çalışma, elde edilen hemiselüloz türevlerinin, endüstriyel kullanıma yönelik biyolojik olarak bozunabilir ve çevre dostu plastik, reçine, film ve kaplama ürünlerinin elde edilmesinde kullanılabileceğini göstermiştir.

Anahtar kelimeler: Sübstitüsyon derecesi, Esterlenme, Hemiselülozlar, Yüzde verim, Çözünürlük, Termal stabilite
\end{abstract}

\section{Introduction}

Due to the gradual depletion of worldwide forest resources, there is a great need for creative use and recycling of natural products to conserve the environment and manage natural resources sustainably. In the wood industry, there are many by-products such as wood shavings and sawdust. Therefore, one of the big troubles in the wood industry is how to enhance the properties and efficiency of wood products using the woody residues and how to recycle them. Among the recognized techniques of wood usage, wood plasticization is a proficient process with potential (Wu et al. 2004).

Black poplar (Populus nigra L.) is a riparian tree species distributed throughout north Africa, central and west Asia, and Europe (Rathmacher et al., 2010). Black poplar plantations in Turkey occupy 70,000 hectares, from which
1.9 million $\mathrm{m}^{3}$ of wood is obtained annually (Kahraman et al., 2011). In total, there are 22.3 million hectares of forest in Turkey, from which 20-20.5 million $\mathrm{m}^{3}$ of wood can be produced annually (OGM, 2016).

The wood of black poplar is utilized as raw material for matches, furniture, packaging, particleboard, fiberboard, plywood, and building components. It has no fragrance, so is also useful for the manufacture of fruit boxes (Gaudet et al., 2008). In recent years, black poplar has received increasing attention as a renewable source for energy and short fiber furnish for paper-making (Stettler et al., 1996). The use of this wood as a raw material in many industrial applications results in the production of a significant amount of black poplar sawdust as waste.

After cellulose, hemicelluloses are the most abundant polysaccharides in wood (Fengel and Wegener, 1984). Being produced from renewable resources and mostly consisting of a Isparta Uygulamalı Bilimler Üniversitesi, Orman Fakültesi, Isparta

@ * Corresponding author (İletişim yazar1): samimyasar@isparta.edu.tr

$\checkmark \quad$ Received (Geliş tarihi): 09.08.2021, Accepted (Kabul tarihi): 22.11.2021
Citation (Atıf): Yaşar, S., Güler, G., 2021. Chemical characterization of black poplar (Populus nigra L.) sawdust hemicelluloses esterified with acyl chlorides. Turkish Journal of Forestry, 22(4): 426-431. DOI: $10.18182 /$ tjf.980457 
production waste, hemicelluloses are economically remarkable raw materials (Williamson and McCormick, 1998). They are characterized by high stability and easy biodegradability, but when mixed with hydrophobic synthetic polymers, the hydrophilic structures of hemicelluloses yield weak surface adhesion and poor mechanical properties in the resultant products. This flaw can be overcome by modifying the molecular structures of hemicelluloses, producing hemicellulosic derivatives. In particular, the hydrophilic -OH groups in hemicelluloses can be converted to hydrophobic groups, and such derivatives have attracted interest as extenders and replacements for polymers prepared from petrochemicals (Fan and Feng, 1987; Fang et al., 1999). Plastic materials of petroleum origin are widely used and characteristically resistant to natural degradation, which causes significant environmental pollution and presents problems for disposal both during production and after use. In addition, it is known that chemicals produced in the recycling of synthetic plastic materials threaten human health (Thompson et al., 2009).

For these reasons, this study investigated the practicability of black poplar sawdust as an additional raw material for the production of hemicellulose derivatives. Hemicelluloses were isolated from black poplar wood sawdust and then esterified with octanoyl, decanoyl, and lauroyl chloride. The resulting derivatives were characterized in terms of percent yield, degree of substitution (DS), solubility, Fourier-transform infrared spectroscopy (FTIR), and thermogravimetric analysis (TGA).

\section{Material and method}

\subsection{Material}

Black poplar sawdust was obtained from Yuceer Sawmill in Isparta-Turkey in 2019. The sawdust was screened between 40 and 100 mesh.

\subsection{Method}

Extractives were removed from sieved sawdust using cyclohexane: ethanol $(2: 1, \mathrm{v} / \mathrm{v})$ extraction for $6 \mathrm{~h}$ in a Soxhlet apparatus. From extract-free sawdust, holocellulose was prepared according to the method of Wise and Karl (1962). Subsequently, the ASTM D1103 (1980) method was performed to isolate hemicelluloses from holocellulose using alkali extraction.

Briefly, the alkali extract containing hemicelluloses was adjusted to $\mathrm{pH} 6$ by the addition of glacial acetic acid. Afterwards, three volumes of $95 \%$ ethanol were added, and this mixture was kept in a deep freeze at $-20{ }^{\circ} \mathrm{C}$ for $24 \mathrm{~h}$ to allow precipitation of hemicelluloses. Precipitated hemicelluloses were centrifuged at 14,000 rpm for $5 \mathrm{~min}$. washed with 95\% ethanol, and then air-dried (Tanriverdi, 2011).

Hemicelluloses ( $1 \mathrm{~g}$, oven-dried weight) were hydrolyzed in $20 \mathrm{~mL} 72 \% \mathrm{HR}_{2} \mathrm{RSOR}_{4} \mathrm{R}$ at $30{ }^{\circ} \mathrm{C}$ for $60 \mathrm{~min}$ and then diluted to $360 \mathrm{~mL}$ with distilled water. After dilution, hydrolysis of hemicelluloses continued at $120{ }^{\circ} \mathrm{C}$ for $60 \mathrm{~min}$ in a JP-Selecta autoclave (Pettersen et al., 1984). Afterwards, monosaccharides were separated from residual lignin by centrifugation at 14,000 rpm for $10 \mathrm{~min}$, and the hydrolysate collected. The monosaccharide composition of hemicelluloses was determined using a Perkin Elmer
Autosystem XL gas chromatograph according to the method developed by Cao et al. (1997).

For esterification, hemicelluloses equivalent to $0.3 \mathrm{~g}$ oven-dried material in $15 \mathrm{~mL}$ distilled water were first incubated at $80{ }^{\circ} \mathrm{C}$ with stirring for $5 \mathrm{~min}$. After adding 15 mL N,N-dimethylformamide (DMF), the mixture was stirred for another 5 min to produce a swollen gel, from which water was removed by evaporation at $50{ }^{\circ} \mathrm{C}$. Acyl chlorides (octanoyl, decanoyl, or lauroyl chloride) were prepared at a molar ratio of 2:1 in accordance with the number of xylose units in the hemicellulloses. To each acyl chloride, $0.075 \mathrm{~g}$ $\mathrm{LiCl}, 0.05 \mathrm{~g}$ 4-dimethylaminopyridine (DMAP), $115 \mu \mathrm{L}$ triethylamine (TEA), and 7.5 mL DMF were added. Prepared acyl chloride mixtures were gradually added to evaporated water-free gels with stirring at $75{ }^{\circ} \mathrm{C}$. These mixtures were incubated with stirring for another $20 \mathrm{~min}$, allowed to cool to room temperature, and then gradually added to $60 \mathrm{~mL}$ ethanol. The resulting ester products were filtered, air-dried for 24 hours, and then dried at $55{ }^{\circ} \mathrm{C}$ for another 24 hours (Fang et al., 1999).

FTIR spectra of the hemicelluloses and ester derivatives were obtained using a Perkin Elmer BX FTIR spectrometer. Briefly, a $10 \mathrm{mg}$ sample was dispersed in a matrix of 1,000 $\mathrm{mg} \mathrm{KBr}$ and pressed to form a self-supporting pellet. The FTIR spectra of pellets were obtained at room temperature between 4000 and $400 \mathrm{~cm}^{-1}$ with a spectral resolution of $4 \mathrm{~cm}^{-}$ 1 .

TGA was carried out using $5 \mathrm{mg}$ of hemicelluloses or ester derivatives in a Perkin Elmer SII Diamond thermograph at a heating rate of $10{ }^{\circ} \mathrm{C} / \mathrm{min}$ across the temperature range of 25-800 ${ }^{\circ} \mathrm{C}$, under nitrogen.

Carbon contents of hemicelluloses and ester derivatives were determined using a Leco CHNS-932 device. DS values of samples were calculated from their carbon contents according to equations $1 \mathrm{a}, 1 \mathrm{~b}$, and $1 \mathrm{c}$. The percent yields of samples were established from their DS values according to equations $2 \mathrm{a}, 2 \mathrm{~b}$, and $2 \mathrm{c}$. Calculations were performed with the assumption that xylan contains two free hydroxyl groups per xylose unit.

$C(\%)=\frac{9608.8 * D S+6005.5}{126.2 * D S+132.1} \quad$ for octanoylated hemicelluloses

$C(\%)=\frac{12011 * D S+6005.5}{155.3 * D S+132.1} \quad$ for decanoylated hemicelluloses

$C(\%)=\frac{14413.2 * D S+6005.5}{182.3 * D S+132.1} \quad$ for lauroylated hemicelluloses

Yield $(\%)=\frac{D S+1.0469}{0.0305}$ for octanoylated hemicelluloses (2a)

Yield $(\%)=\frac{D S+0.8531}{0.0286}$ for decanoylated hemicelluloses $(2 \mathrm{~b})$

Yield $(\%)=\frac{D S+0.7248}{0.0272}$ for lauroylated hemicelluloses

Solubility was measured using $5 \mathrm{~g}$ of hemicellulose or ester derivatives in $100 \mathrm{~mL}$ each of pyridine, dimethylsulfoxide (DMSO), tetrahydrofuran (THF), toluene, chloroform, and dichloromethane solvents. 


\section{Results and discussion}

3.1. Monosaccharide composition of hemicelluloses from black poplar sawdust

Black poplar sawdust contained a large quantity of hemicelluloses, comprising $21.47 \%$ of oven-dried material. Isolated hemicelluloses included residual lignin in the amount of $3.68 \%$. By gas chromatography, the highestcontent monosaccharide unit in the hemicelluloses of black poplar sawdust was xylose, at $81.13 \%$ (Figure 1). Other monosaccharides were glucose, galactose, rhamnose, arabinose, and mannose in the respective amounts of $2.14 \%$, $3.61 \%, 1.22 \%, 3.58 \%$, and $4.64 \%$.

3.2. Carbon contents, DS values, and percent yields of esterified hemicelluloses

If no esterification of hemicelluloses occurred, the subsequent carbon content would be $45.46 \%$ and the DS value would be 0 . In contrast, if all of the recovered hemicelluloses had reacted, the octanoylated, decanoylated, and lauroylated hemicelluloses would have respective carbon contents of $65.60 \%, 68.15 \%$, and $70.12 \%$, and the DS values would be 2 for all three esterified hemicelluloses. The determined carbon contents were $59.03 \%, 61.94 \%$, and $64.70 \%$, for octanoylated, decanoylated, and lauroylated hemicelluloses, respectively. From these values, the DS values were calculated as $0.83,0.91$, and 0.97 , respectively, for octanoylated, decanoylated, and lauroylated hemicelluloses (Table 1).

If the hemicelluloses did not react with the acyl chlorides (DS=0), the percent yields would be $34.36 \%$ for octanoylation, $29.98 \%$ for decanoylation, and $26.60 \%$ for lauroylation. If the hemicelluloses fully reacted with the acyl chlorides during esterification ( $\mathrm{DS}=2$ ), the percent yield would be $100 \%$ for each hemicellulose ester. The percent yields determined from DS values were $61.54 \%$ for octanoylation, $61.65 \%$ for decanoylation, and $62.31 \%$ for lauroylation (Table 2).

The DS values and percent yields obtained in this study are consistent with findings reported in the literature (Yaşar, 2018; Fang et al., 1999; Sun et al., 1999, 2000; Ren et al., 2008; Xu et al., 2008; Tanrıverdi, 2011) for different native hemicelluloses where those hemicelluloses were esterified with octanoyl, decanoyl, and lauroyl chlorides at a molar ratio of $1: 2$.

\subsection{FTIR spectra of hemicelluloses and esterified hemicelluloses}

FTIR spectra of the hemicelluloses and the esterified hemicelluloses are given in Figure 2, and the band frequencies with their assignments are given in Table 3.

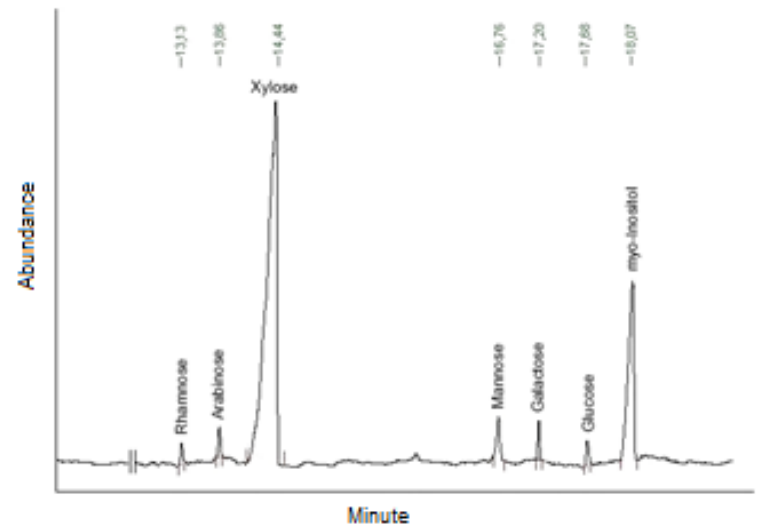

Figure 1. GC chromatogram of monosaccharides in hemicelluloses of black poplar sawdust.

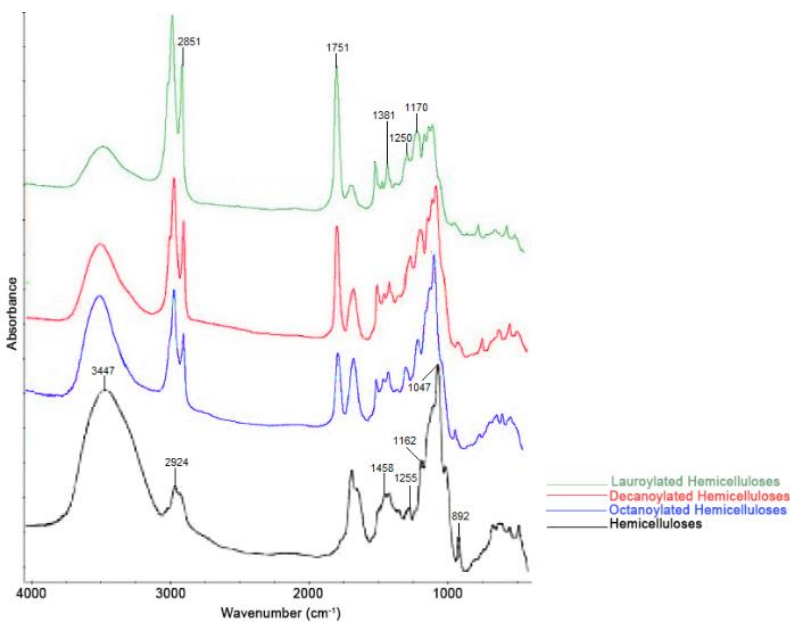

Figure 2. FTIR spectra of hemicelluloses and esterified hemicelluloses.

Table 1. Carbon contents and DS values of esterified hemicelluloses.

\begin{tabular}{cccccc}
\hline $\begin{array}{c}\text { Hemicellulose } \\
\text { ester }\end{array}$ & $\begin{array}{c}\text { Molar } \\
\text { ratio* }\end{array}$ & $\begin{array}{c}\text { \% for } \\
\mathrm{DS}=0\end{array}$ & $\begin{array}{c}\text { \%C for } \\
\mathrm{DS}=2\end{array}$ & \%C & $\mathrm{DS}$ \\
\hline $\begin{array}{c}\text { Octanoylated } \\
\text { sample }\end{array}$ & $1: 2$ & 45.46 & 65.60 & 59.03 & 0.83 \\
$\begin{array}{c}\text { Decanoylated } \\
\text { sample }\end{array}$ & $1: 2$ & 45.46 & 68.15 & 61.94 & 0.91 \\
$\begin{array}{c}\text { Lauroylated } \\
\text { sample }\end{array}$ & $1: 2$ & 45.46 & 70.12 & 64.70 & 0.97 \\
\hline *.
\end{tabular}

*: mol of xylose units in hemicelluloses/mol of OC, DC or LC.

Table 2. Yields of esterified hemicelluloses.

\begin{tabular}{|c|c|c|c|c|c|c|}
\hline Hemicellulose ester & Molar ratio* & Temperature $\left({ }^{\circ} \mathrm{C}\right)$ & Time (min) & Yield $(\%)$ for $\mathrm{DS}=0$ & Yield $(\%)$ for $\mathrm{DS}=2$ & Yield $(\%)$ \\
\hline Octanoylated sample & $1: 2$ & 75 & 30 & 34.36 & 100 & 61.54 \\
\hline Decanoylated sample & $1: 2$ & 75 & 30 & 29.98 & 100 & 61.65 \\
\hline Lauroylated sample & $1: 2$ & 75 & 30 & 26.60 & 100 & 62.31 \\
\hline
\end{tabular}


Table 3. Spectral interpretations from FTIR analysis of hemicelluloses and esterified hemicelluloses.

\begin{tabular}{cll}
\hline Band $\left(\mathrm{cm}^{-1}\right)$ & Assignment & Reference \\
\hline 3447 & H-bonded H-O stretching & Sun et al., 1999 \\
2924 & aliphatic CHR ${ }_{3}$ R stretching & Joly et al., 2006 \\
2851 & aliphatic CHR ${ }_{2}$ R stretching & Joly et al., 2006 \\
1751 & C-O (ester) stretching & Saikia et al., 1995; Joly et al., 2006 \\
$1458-1047$ & C-H and C-O stretching in hemicelluloses & Wang et al., 2012 \\
1381 & C-H bending & Sun et al., 1999 \\
1250 & C-O stretching & Saikia et al., 1995; Yang and Wang, 1996 \\
1170 & C-C stretching & Sun et al., 1999 \\
892 & characteristic of $\beta$-glycosidic linkage between the sugar units in hemicelluloses & Gupta et al., 1987 \\
\hline
\end{tabular}

The FTIR bands at 3447, 2924, 1458, 1255, 1162, 1047, and $892 \mathrm{~cm}^{-1}$ are declarative of hemicelluloses. The intensities of all these characteristic bands were markedly reduced in the esterified products. Additionally, the appearance of distinctive bands at 2851, 1751, 1381, 1250, and $1170 \mathrm{~cm}^{-1}$ in the spectra of octanoylated, decanoylated, and lauroylated hemicelluloses is indicative of esterified hemicelluloses. Successful esterification is further confirmed by an observed decrease in intensity of the band at $3447 \mathrm{~cm}^{-}$ ${ }^{1}$; an increase in the intensities of the bands at 2924, and 2851 $\mathrm{cm}^{-1}$; and the appearance of ester bands at 1751 and $1170 \mathrm{~cm}^{-}$ ${ }^{1}$ in the spectra of esterified products. The changes in the intensity of the spectral bands could be interpreted in terms of reduction in the quantity of hydrogenbonded hydroxyl groups as they were transformed into ester groups. The band at $3447 \mathrm{~cm}^{-1}$ and the bands at 2924, 2851, 1751, and $1170 \mathrm{~cm}^{-}$ ${ }^{1}$ were affected in proportion with the increasing DS values of esterified hemicelluloses.

\subsection{TGA and DTG thermograms of hemicelluloses and esterified hemicelluloses}

Thermograms from TGA and differential thermogravimetric analysis (DTG) of the hemicelluloses and esterified hemicelluloses are given in Figure 3.

During thermal decomposition, it was observed that water was removed from native hemicelluloses until a temperature of $145{ }^{\circ} \mathrm{C}$ and from esterified hemicelluloses until a temperature of $115^{\circ} \mathrm{C}$. The actual decomposition occurred at temperatures from 145 to $567{ }^{\circ} \mathrm{C}$ for native hemicelluloses, 115 to $481{ }^{\circ} \mathrm{C}$ for octanoylated hemicelluloses, 115 to $463{ }^{\circ} \mathrm{C}$ for decanoylated hemicelluloses, and 115 to $429{ }^{\circ} \mathrm{C}$ for lauroylated hemicelluloses. In native hemicelluloses, maximum degradation occurred at $305^{\circ} \mathrm{C}$. Relative to native hemicelluloses, the maximum degradation temperature decreased by $40{ }^{\circ} \mathrm{C}$ in octanoylated hemicelluloses, $52{ }^{\circ} \mathrm{C}$ in decanoylated hemicelluloses, and $63{ }^{\circ} \mathrm{C}$ in lauroylated hemicelluloses. The quantities of carbonized residue obtained at the end of thermal decomposition $\left(800^{\circ} \mathrm{C}\right)$ were $9.89 \%$ for native hemicelluloses, $7.63 \%$ for octanoylated hemicelluloses, $4.39 \%$ for decanoylated hemicelluloses, and $3.54 \%$ for lauroylated hemicelluloses.
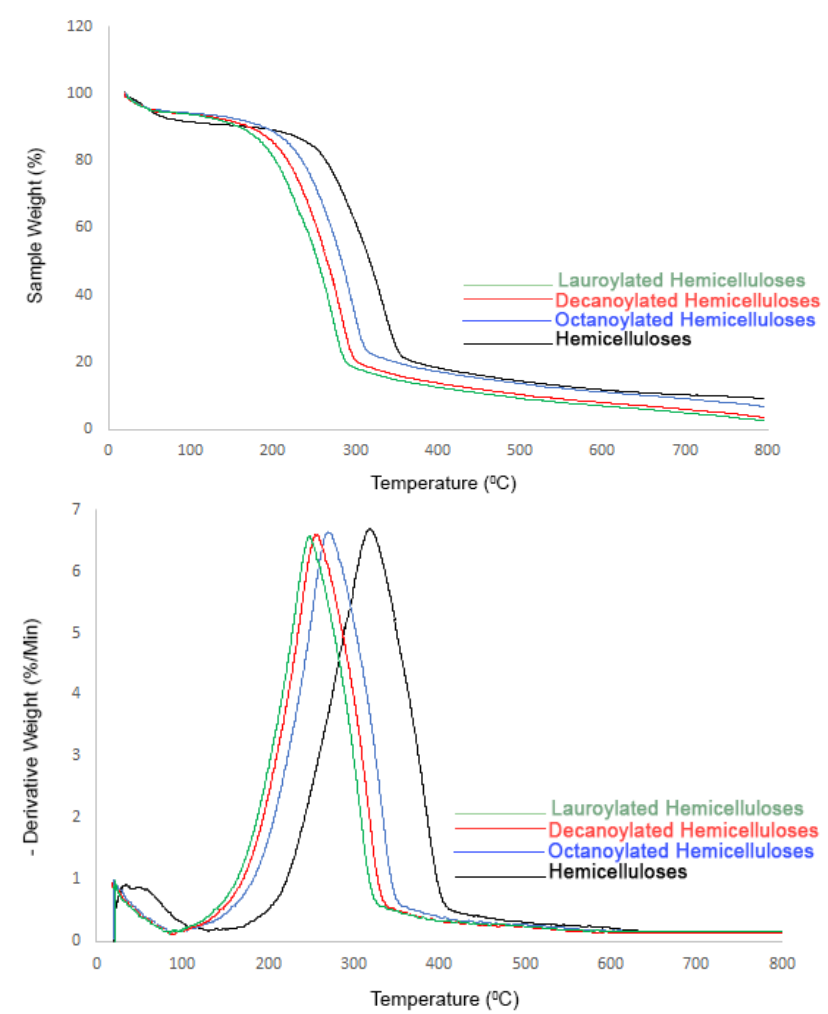

Figure 3. TGA and DTG thermograms of hemicelluloses and esterified hemicelluloses.

These findings indicate that the esterified products have lower thermal stability than the native hemicelluloses, and this stability continuously decreased with increasing DS values. These findings are consistent with the study by Wang et al. (2012) showing that the weak thermal stability of esterified products is potentially due to the acyl group attached to the hemicelluloses and to the depolymerization of derivaives in the solvent system during esterification. Moreover, partial degradation may occur from conversion of the hydrophilic $\mathrm{OH}$ groups of hemicelluloses in the solvent system to hydrophobic groups.

\subsection{Solubility of esterified hemicelluloses}

Hemicelluloses are by nature hydrophilic polymers owing to the $\mathrm{OH}$ groups (Fengel and Wegener, 1984). Hydrophobic acyl groups introduced into the structures of hemicelluloses are expected to change the solubility. In addition to the depolymerization that occurs during esterification, the participation of acyl groups in a hemicellulosic polymer may open the molecular structure of hemicelluloses, improving the solubility of ester derivatives (Sun et al., 1999). Such a change in solubility would fundamentally rely on the DS. In the literature, it was reported 
that polysaccharides esterified with acyl chlorides were soluble in pyridine and in dimethylsulfoxide (DMSO), while those with low DS values were only partially soluble in tetrahydrofuran (THF), toluene, chloroform, and dichloromethane (Rahn et al., 1996; Lepeniotis and Feuer, 1997; Sun et al., 1999 and 2000). In this study, hemicellulosic derivatives produced by octanoylation, decanoylation, and lauroylation with low DS values from 0.83 to 0.97 solubilized in pyridine at a temperature of $80{ }^{\circ} \mathrm{C}$ and in dimethylsulfoxide (DMSO) at temperature of $45^{\circ} \mathrm{C}$, and partially solubilized in tetrahydrofuran (THF), toluene, chloroform and dichloromethane at room temperature. These findings indicate that the esterification of hemicelluloses isolated from black poplar sawdust using octanoylation, decanoylation, and lauroylation improved their hydrophobic capacity.

\section{Conclusion}

Black poplar sawdust is widely available as lignocellulosic waste generated by the wood industry. In this study, the feasibility of using black poplar sawdust as a raw material for the production of hemicellulose derivatives was investigated. Isolated hemicelluloses comprised $21.47 \%$ of oven-dried black poplar sawdust, and xylose was the predominant monosaccharide unit, at $81.13 \%$. The obtained hemicelluloses were esterified with octanoyl, decanoyl, and lauroyl chloride. The esterified hemicelluloses had low DS values (0.83-0.97) and percent yields (61.54-62.31\%). A continuous decrease in the intensity of the FTIR spectral band at $3447 \mathrm{~cm}^{-1}$ and continuous increase in the intensities of the bands at 2924, 2851, 1751, and $1170 \mathrm{~cm}^{-1}$ with increasing DS values confirmed the esterification of hemicelluloses. The esterified derivatives had lower thermal stability than the native hemicelluloses, and stability decreased with increasing DS values. Solubility analysis showed that the esterification of hemicelluloses improved their hydrophobic capacity. Generally, the study indicated that the obtained hemicellulose derivatives could be used as raw material in the production of biodegradable and environmentally friendly plastics, resins, films, and coatings for industrial utilization.

\section{References}

ASTM D1103, 1980. Standard test method for alpha-cellulose in wood. ASTM International, West Conshohocken, USA.

Cao, B., Tschirner, U., Ramaswamy, S., Webb, A., 1997. A rapid modified gas chromatographic method for carbohydrate analysis of wood pulps. TAPPI Journal, 80(9): 193-197.

Fan, X.R., Feng, Z.H., 1987. Effects of carboxymethyl-modified hemicellulose on the activity of T lymphocytes and the amount of immunocytes. Zhongguo yao li xue bao: Acta pharmacologica Sinica, 8(2): 169-173.

Fang, J.M., Sun, R., Fowler, P., Tomkinson, J., Hill, C.A.S., 1999. Esterification of wheat straw hemicelluloses in the N, Ndimethylformamide/lithium chloride homogeneous system. Journal of Applied Polymer Science, 74(9): 2301-2311.

Fengel, D., Wegener, G., 1984. Wood Chemistry, Ultrastructure, Reactions. Walter de Gruyter Verlag, Berlin, Germany.

Gaudet, M., Jorge, V., Paolucci, I., Beritognolo, I., Mugnozza, G.S., Sabatti, M., 2008. Genetic linkage maps of Populus nigra L. including AFLPs, SSRs, SNPs, and sex trait. Tree Genetics \& Genomes, 4(1): 25-36.

Gupta, S., Madan, R.N., Bansal, M.C., 1987. Chemical composition of Pinus caribaea hemicellulose. Tappi Journal, 70(8): 113-116.
Joly, N., Martin, P., Lienard, L., Rutot, D., Stassin, F., Granet, R., 2006. Effect of degree of substitution on the mechanical and thermomechanical properties of lauroyl cellulose ester film. EPolymers, 6(1): 1-9.

Kahraman, T., Kahraman, F.K., Karakaya, S., Karahan, A., Ünsal, G., Karatay, H., Toplu, F., 2011. Türkiye'de Karakavakta (Populus nigra L.) Islah Çalışmaları 'Fidanlık Aşaması Sonuçları'. Teknik Bülten No: 210, T.C. Orman ve Su İşleri Bakanlığı Kavak ve Hızlı Gelişen Orman Ağaçları Araştırma Enstitüsü Müdürlüğ̈̈, İzmit, Türkiye.

Lepeniotis, S., Feuer, B.I., 1997. Synthesis of starch acetate: Statistical designed experiments to optimize the reaction conditions. Chemometrics and Intelligent Laboratory Systems, 36(2): 229-243.

OGM, 2016. Oduna Dayalı Orman Ürünlerinin Üretim ve Pazarlama Faaliyetleri. Ankara, Türkiye.

Pettersen, R.C., Schwandt, V.H., Effland, M.J., 1984. An analysis of the wood sugar assay using HPLC: a comparison with paper chromatography. Journal of Chromatographic Science, 22(11): 478-484.

Rahn, K., Diamantoglou, M., Klemm, D., Berghmans, H., Heinze, T., 1996. Homogeneous synthesis of cellulose ptoluenesulfonates in $\mathrm{N}, \mathrm{N}$-dimethylacetamide/ $\mathrm{LiCl}$ solvent system. Die Angewandte Makromolekulare Chemie: Applied Macromolecular Chemistry and Physics, 238(1): 143-163.

Rathmacher, G., Niggemann, M., Köhnen, M., Ziegenhagen, B., Bialozyt, R., 2010. Short-distance gene flow in Populus nigra L. accounts for small-scale spatial genetic structures: Implications for in situ conservation measures. Conservation Genetics, 11(4): $1327-1338$

Ren, J., Xu, F., Sun, R.C., Peng, B., Sun, J., 2008. Studies of the Lauroylation of Wheat Straw Hemicelluloses under Heating. Journal of Agricultural and Food Chemistry, 56(4): 1251-1258.

Saikia, C.N., Ali, F., Goswami, T., Ghosh, A.C., 1995. Esterification of high a-cellulose extracted from Hibiscus cannabinus L. Industrial Crops and Products, 4(4): 233-239.

Stettler, R., Bradshaw, T., Heilman, P., Hinckley, T., 1996. Biology of Populus and its Implications for Management and Conservation. NRC Research Press, Ottawa, Canada.

Sun, R.C., Fang, J.M., Tomkinson, J., 2000. Characterization and esterification of hemicelluloses from rye straw. Journal Agricultural Food Chemistry, 48(4): 1247-1252.

Sun, R.C., Fang, J.M., Tomkinson, J., Hill, C.A.S., 1999. Esterification of Hemicelluloses from Poplar Chips in Homogenous Solution of N,N-Dimethylformamide/Lithium Chloride. Journal of Wood Chemistry and Technology, 19(4): 287-306.

Tanrıverdi, H., 2011. Haşhaş sap1 (Papaver somniferum L.) hemiselülozlarının N,N-dimetilformamit/lityum klorür homojen sisteminde esterifikasyonu. Doktora Tezi, Süleyman Demirel Üniversitesi, Fen Bilimleri Enstitüsü, Isparta.

Thompson, R.C., Moore, C.J., Vom Saal, F.S., Swan, S.H., 2009. Plastics, the environment and human health: current consensus and future trends. Philosophical transactions of the royal society B: Biological sciences, 364(1526): 2153-2166.

Wang, H.T., Yuan, T.Q., Meng, L.J., She, D., Geng, Z.C., Sun, R.C., 2012. Structural and thermal characterization of lauroylated hemicelluloses synthesized in an ionic liquid. Polymer degradation and stability, 97(11): 2323-2330.

Williamson, S.L., McCormick, C.L., 1998. Cellulose derivatives synthesized via isocyanate and activated ester pathways in homogeneous solutions of lithium chloride/N, Ndimethylacetamide. Journal of Macromolecular Science, Part A: Pure and Applied Chemistry, A35(12): 1915-1927.

Wise, E.L., Karl, H.L., 1962. Cellulose and Hemicellulose in Pulp and Paper Science and Technology. Libby, C.E. (Ed.), Vol:1, Mc Graw Hill Book Co., New York, USA.

Wu, J.H., Hsieh, T.Y., Lin, H.Y., Shiau, I.L., Chang, S.T., 2004. Properties of wood plasticization with octanoyl chloride in a solvent-free system. Wood Science and Technology, 37(5): 363 372. 
Xu, F., Jiang, J.X., Sun, R.C., She, D., Peng, B., Sun, J.X., Kennedy, J.F., 2008. Rapid esterification of wheat straw hemicelluloses induced by microwave irradiation. Carbohydrate Polymers, 73(4): 612-620.

Yang, C.Q., Wang, X., 1996. Formation of cyclic anhydride intermediates and esterification of cotton cellulose by multifunctional carboxylic acids: An infrared spectroscopy study. Textile Research Journal, 66(9): 595-603.
Yaşar, S., 2018. Ilgın (Tamarix parviflora) hemiselülozlarının oktanoil, dekanoil ve lauroil klorür ile esterlenmesi. Mehmet Akif Ersoy Üniversitesi Fen Bilimleri Enstitüsü Dergisi, 9(1): 91-97. 